\title{
Relationship between Mycoplasma mycoides subsp. mycoides ('Large-colony' Strains) and $M$. mycoides subsp. capri, as Indicated by Numerical Analysis of One-dimensional SDS-PAGE Protein Patterns
}

\author{
By R. H. LEACH, ${ }^{1,2}$ M. COSTAS ${ }^{1 *}$ AND DEBORAH L. MITCHELMORE ${ }^{1,2}$ \\ ${ }^{1}$ National Collection of Type Cultures, and ${ }^{2}$ PHLS Mycoplasma Reference Facility (NCTC), \\ Central Public Health Laboratory, Colindale Avenue, London NW9 5HT, UK
}

(Received 6 January 1989; revised 17 July 1989; accepted 28 July 1989)

\begin{abstract}
Twenty-five strains classified as Mycoplasma mycoides subsp. mycoides LC or subsp. capri have been compared by one-dimensional SDS-PAGE of their cellular proteins. A computerized numerical analysis revealed that the protein patterns of all but two aberrant strains formed one large phenon that separated clearly from representatives of the four other members of the 'M. mycoides cluster' at a similarity level $(S)$ of $66 \%$ and which remained undivided at up to $78 \%$ $S$. At higher similarity levels, these strains fell heterogeneously into mixed sub-phenons containing strains of both subspecies. Serological comparisons by immunofluorescence largely confirmed the subspecies designations of the test strains, but also showed that some were serologically intermediate between subsp. mycoides and subsp. capri, being cross-reactive with both. These results confirm and enlarge upon those of our earlier studies indicating the proteinpattern inseparability of subsp. capri and subsp. mycoides LC strains and their distinctiveness from the classical $M$. mycoides subsp. mycoides SC strains and other members of the ' $M$. mycoides cluster'. As also recognized by other workers, subsp. mycoides LC and subsp. capri strains appear to comprise one large group, wherein those most readily identifiable as either type lie at either end of a serological spectrum that also contains serologically cross-reactive strains. Our observations therefore suggest the lines along which the three groups classified at present within the species M. mycoides (SC and LC strains of subsp. mycoides; subsp. capri) might eventually be reclassified, subject to direct genomic comparisons.
\end{abstract}

\section{INTRODUCTION}

The species Mycoplasma mycoides at present contains two serologically-based subspecies, subsp. mycoides and subsp. capri. Strains distinguishable by serology as subsp. mycoides comprise two biological types (Cottew \& Yeats, 1978). The so-called 'small-colony' (SC) strains of subsp. mycoides are found mainly in cattle, as the causative agent of the classical disease, contagious bovine pleuropneumonia. The other type, the 'large-colony' (LC) strains, are pathogenic for goats, their main host; they grow much more profusely and produce considerably larger colonies than the SC strains, despite their serological similarity. $M$. mycoides subsp. capri, also from goats, is serologically different from both SC and LC strains of subsp. mycoides, although very similar in cultural and biochemical characteristics to the LC strains. A complicating factor is that some isolates presumed to be the LC type do show serological crossreactivity with $M$. mycoides subsp. capri, or vice versa, making their precise typing difficult (Cottew, 1979; Salih et al., 1983; Nascimento et al., 1986).

Abbreviation: IF, immunofluorescence. 
The taxonomic relationships between the above three groups of mycoplasmas are therefore unclear. Furthermore, they fall within a larger 'problem-cluster' that also contains three other bovine or caprine/ovine mycoplasma groups - the so-called ' $M$. mycoides cluster' (Cottew et al., 1987). The overall relationships of all six groups have been examined previously by an analysis of their one-dimensional SDS-PAGE protein patterns (Costas et al., 1987a). In that study, each of the six ' $M$. mycoides cluster' groups was represented by the type/reference strain and a few other isolates. Despite their known serological differences, $M$. mycoides subsp. capri and the LC strains of subsp. mycoides, on the basis of their compared protein patterns, formed a single phenon, at the $70 \%$ similarity $(S)$ level, that was distinct from that of the SC strains of subsp. mycoides and from all other 'cluster' members. Moreover, the subsp. capri and the LC strains could not be clearly separated from each other even at $75 \% \mathrm{~S}$, where they fell heterogeneously into several sub-taxa. However, in that investigation, these two groups were each represented by only four or five strains and it was desirable to determine whether their apparent inseparability would be confirmed by similar studies with larger numbers of isolates of each group.

For the present study, further isolates were gathered that had already been classified elsewhere as either subsp. capri or subsp. mycoides LC, plus some strains provisionally classified as subsp. capri but serologically cross-reactive also with subsp. mycoides LC (Nascimento et al., 1986). These additional strains, together with those previously tested, were checked serologically in this laboratory and all 25 strains were also examined together by one-dimensional SDSPAGE. As previously, their protein patterns were compared in a computerized numerical analysis, in order to provide further insight into their possible taxonomic relationships.

\section{METHODS}

Mycoplasma strains. The 25 strains to be compared and their origins are shown in Table 1. These comprised eight strains from goats classified as $M$. mycoides subsp. capri, including the type strain PG3 (two samples), together with 12 goat strains classified as $M$. mycoides subsp. mycoides LC, including the reference strain, Y-goat, plus five Brazilian isolates (nos 22-26), tentatively classified as subsp. capri but serologically cross-reactive also with subsp. mycoides LC (Nascimento et al., 1986). The type/reference strains for the other four members of the 'M. mycoides cluster' (viz. M. mycoides subsp. mycoides SC, Bovine serogroup 7, F38 type and M. capricolum) were also included (Table 1, nos 27-30) for comparative purposes, providing reference 'markers' to our previous results (Costas et al., 1987a). The sources of some of these strains have been indicated previously (Costas et al., 1987a). Most of the others were provided through the courtesy of G. S. Cottew (LC and capri strains) and E. A. Freundt (Brazilian isolates of Nascimento et al., 1986). Additional individual strains were kindly provided by A. J. Da Massa (GM12) and G. R. Smith (Pendik).

Serological tests. The mycoplasmas were compared serologically by a modification of the indirect immunofluorescence (IF) test applied to unfixed colonies on agar blocks (Rosendal \& Black, 1972; Gardella et al., 1983), using specific hyperimmune rabbit serum as the primary reagent and sheep anti-rabbit fluorescein isothiocyanate conjugate as the secondary reagent. The rabbit antisera used were specific reference sera prepared against $M$. mycoides subsp. mycoides SC ('Gladysdale'), subsp. mycoides LC (GM12) and subsp. capri (PG3). The 'Gladysdale' and PG3 antisera were kindly donated by R. M. Lemcke and the GM12 antiserum by A. J. Da Massa; the PG1 and alternative PG3 antisera referred to in Table 2 (footnote) were prepared in this laboratory.

Cultural and biochemical properties. All the test strains of $M$. mycoides subsp. mycoides LC and subsp. capri conformed in their general properties to those expected for these mycoplasmas, in that they all grew rapidly and profusely in broth, produced very large colonies on agar and produced strong acidity in glucose broth, but did not hydrolyse arginine (Cottew, 1979).

Preparation of protein samples. Glucose-broth cultures of each strain were grown and harvested to produce a cell pellet which was treated with double-strength lysis buffer. This was heated and centrifuged to give a supernatant containing the water-soluble proteins. Full details of the methods used to grow, harvest and prepare protein samples for electrophoresis have been published previously (Costas et al., 1987a).

Electrophoresis. Discontinuous gels $(16 \times 18 \times 0.15 \mathrm{~cm})$ were cast to allow for $10 \mathrm{~mm}$ of stacking gel. The separation and stacking gels were prepared to give final polyacrylamide contents of $10 \%$ and $5 \%$ (w/v) respectively. Electrophoresis was done as described previously (Costas et al., 1987a) for about $4 \mathrm{~h}$ in a Protean double-slab vertical electrophoresis cell (Bio-Rad) at a constant current of $30 \mathrm{~mA}$ per gel, until the marker dye had migrated $100 \mathrm{~mm}$ along the length of the separation gel.

Scanning of gels, analysis of data and computation of similarity. The stained protein patterns in the dried gels were scanned using an LKB 2222 Ultroscan XL laser densitometer (Pharmacia-LKB Biotechnology). Analysis and 
Table 1. Mycoplasma strains used and their sources

\begin{tabular}{|c|c|c|c|}
\hline $\begin{array}{l}\text { Reference no. } \\
\text { in dendrogram }\end{array}$ & $\underset{\text { designation* }}{\text { Strain }}$ & $\begin{array}{l}\text { Country of } \\
\text { isolation }\end{array}$ & $\begin{array}{l}\text { Obtained } \\
\text { from } †\end{array}$ \\
\hline \multicolumn{4}{|c|}{ M. mycoides subsp. capri } \\
\hline $2 ; 20$ & PG3 $\left(=\right.$ NCTC $\left.10137^{\mathrm{T}}\right)$ & Turkey & 2 \\
\hline 1 & N108 & Nigeria & 1 \\
\hline 6 & YC & Australia & 1 \\
\hline 8 & $\mathbf{Z Z}$ & Australia & 4 \\
\hline 10 & $74.5907 \mathrm{~A}$ & Australia & 4 \\
\hline 12 & $\mathrm{JM}$ & Australia & 1 \\
\hline 14 & Pendik & Turkey & 4 \\
\hline 19 & BQT & Turkey & 4 \\
\hline \multicolumn{4}{|c|}{ M. mycoides subsp. mycoides $\mathrm{LC}$} \\
\hline 3 & 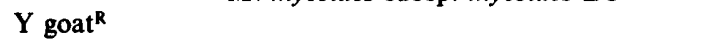 & Australia & 1 \\
\hline 4 & F30(M2055/75) & Kenya & 5 \\
\hline 5 & VRI/3172.LB2 & Australia & 1 \\
\hline 7 & $74 / 2488$ & Australia & 4 \\
\hline 9 & $81.636 .1 \mathrm{C}$ & Australia & 1 \\
\hline 11 & GE.6A.79E & Australia & 1 \\
\hline 13 & KH1 & Australia & 1 \\
\hline 15 & Ojo 1 & Nigeria & 4 \\
\hline 16 & $78 / 441$ & Australia & 1 \\
\hline 17 & $\operatorname{Cov} 2$ & Turkey & 4 \\
\hline 18 & GM12 & USA & 6 \\
\hline 21 & $1217 / 77$ & Australia & 1 \\
\hline \multicolumn{4}{|c|}{ Brazilian isolates } \\
\hline 22 & $\mathrm{G} 108 / \mathrm{A} 2$ clone $\mathrm{b}$ & Brazil & 3 \\
\hline 23 & G108/A2 clone a & Brazil & 3 \\
\hline 24 & G169/Leite & Brazil & 3 \\
\hline 25 & G108/A3 & Brazil & 3 \\
\hline 26 & G105/A1 & Brazil & 3 \\
\hline \multicolumn{4}{|c|}{ Other members of the 'M. mycoides cluster' } \\
\hline 27 & M. mycoides subsp. mycoides SC $\left(\mathrm{PG} 1=\right.$ NCTC $\left.10114^{\mathrm{T}}\right)$ & & 2 \\
\hline 28 & Bovine serogroup $7\left(\mathrm{~N} 29=\mathrm{NCTC} 10133^{\mathrm{R}}\right)$ & & 2 \\
\hline 29 & Strain F38 (NCTC 10192R) & & 2 \\
\hline 30 & M. capricolum (California kid $=$ NCTC $10154^{\mathrm{T}}$ ) & & 2 \\
\hline
\end{tabular}

computation of similarity were based on the correlation coefficient and were essentially as published elsewhere (Costas et al., 1989). Specific details of the parameter settings used in the analysis of PAGE protein patterns are available from the authors.

\section{RESULTS}

One-dimensional SDS-PAGE of whole-cell protein extracts of strains of $M$. mycoides subsp. mycoides LC and subsp. capri produced patterns containing over 50 discrete bands corresponding to molecular sizes of 18-100 kDa (Fig. 1). Protein samples of strain PG3 run on the two different gels used gave a similarity $(S)$ value of $98 \%$, indicating a high level of reproducibility for the study.

A numerical analysis comparing the protein patterns indicated that all but two of the strains previously assigned to $M$. mycoides subsp. mycoides LC and subsp. capri clustered together in one phenon that separated at $66 \% S$ and was undivided up to $78 \% S$, as shown in the dendrogram (Fig. 2). The two strains that fell outside this large cluster were the subsp. capri strains, N108 and 


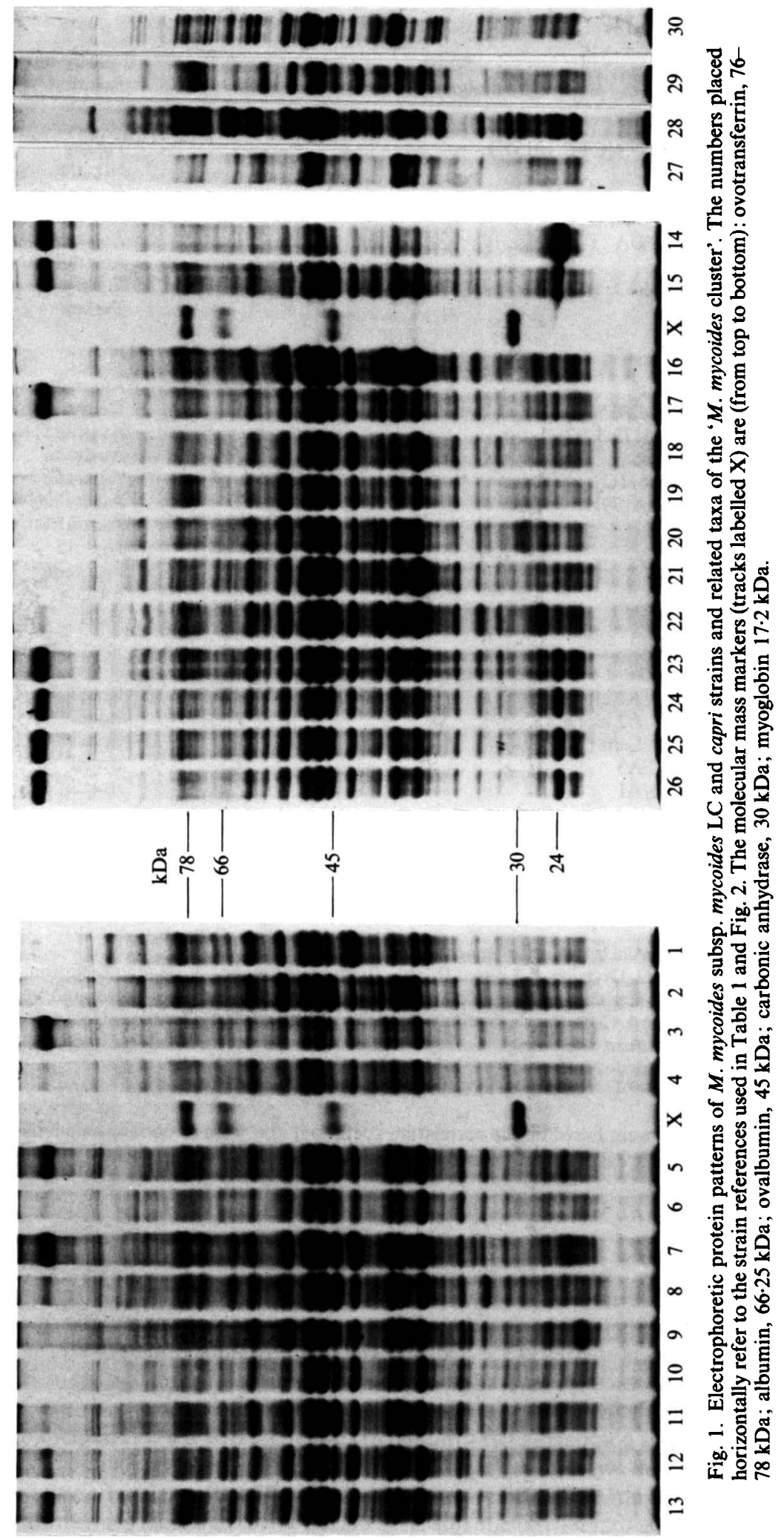




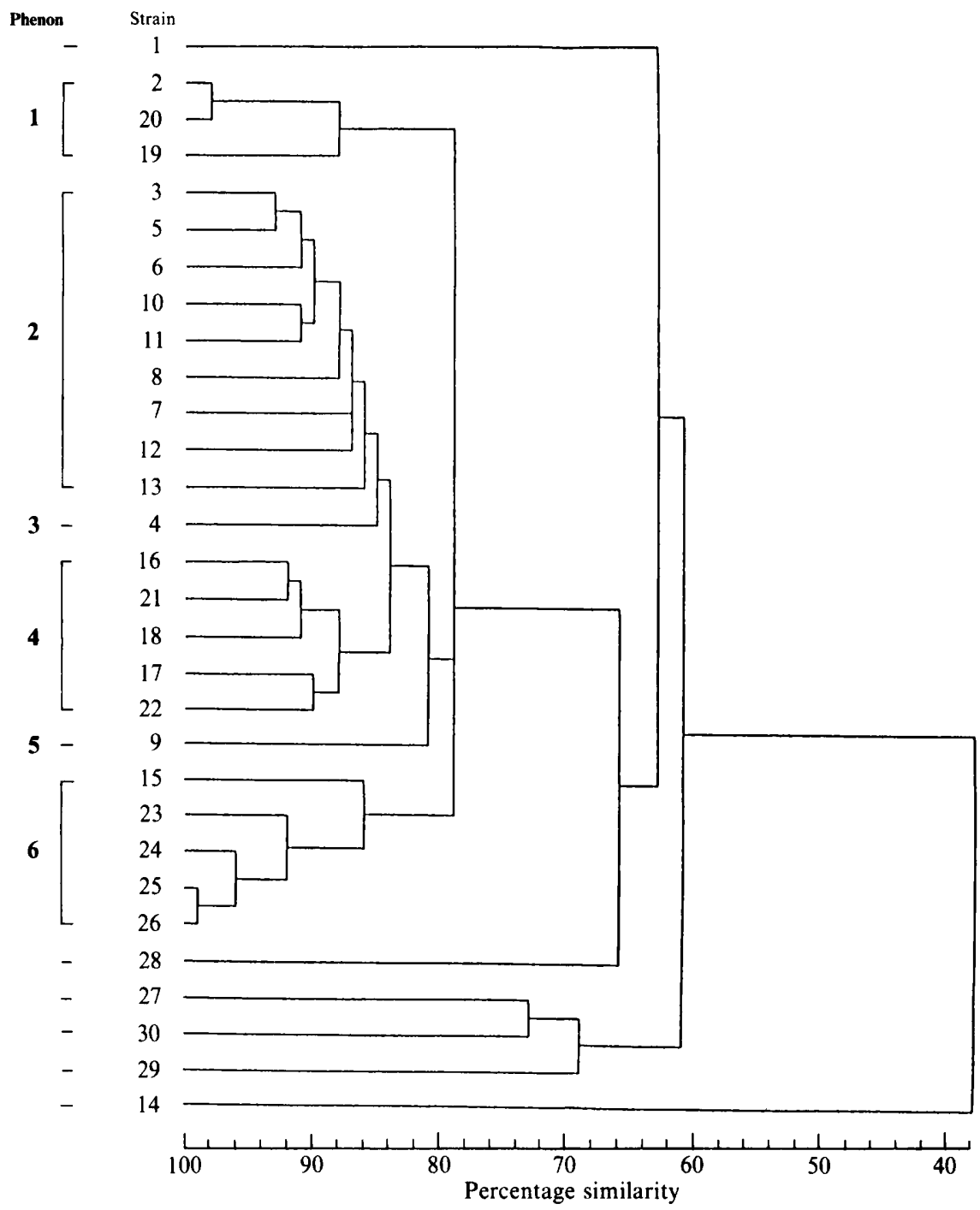

Fig. 2. Dendrogram of the cluster analysis based on total protein content of strains (vertical axis) listed in Table 1. The numbers on the horizontal axis indicate the percentage similarities as determined by the Pearson product moment correlation coefficient and UPGMA clustering. Numbers defined by the brackets are the sub-phenons formed at the $85 \%$ similarity level.

Pendik. Examination of their protein patterns (Fig. 1) indicates that the main differences accounting for their anomalous positions reside in the presence of an additional band at $36 \mathrm{kDa}$ in the N108 pattern and an intense band at $24 \mathrm{kDa}$ in the Pendik pattern, both of which were confirmed by repeat testing. Such heavy banding has been previously shown to cause strains to fall outside their appropriate cluster (Costas et al., 1987a).

The 23 strains that were inseparable up to $78 \% S$ fell heterogeneously into further subphenons when compared at higher similarity levels. At $80 \% S$, the majority of subsp. capri and subsp. mycoides LC strains fell into one of three sub-phenons and even at $85 \% S$, where there were six sub-phenons, the largest was mixed, containing four subsp. capri and five subsp. mycoides LC strains (Fig. 2). It is interesting to note that all nine strains included in this subphenon were originally isolated in Australia, although isolates from that country were also found 
Table 2. Serological comparison of test strains

Titres obtained in indirect colony IF tests against antisera to:

\begin{tabular}{|c|c|c|c|c|}
\hline & $\begin{array}{l}\text { Strain reference no. } \\
\text { and designation }\end{array}$ & $\begin{array}{c}{ }^{*} M . \text { mycoides subsp. } \\
\text { mycoides SC } \\
\text { (Gladysdale } \dagger \text { ) }\end{array}$ & $\begin{array}{l}\text { M. mycoides subsp. } \\
\text { mycoides LC } \\
\text { (GM12) }\end{array}$ & $\begin{array}{c}\text { M. mycoides subsp. } \\
\text { capri } \\
\text { (PG3) }\end{array}$ \\
\hline 27 & $\begin{array}{l}\text { M. mycoides } \\
\text { subsp. mycoides SC (PG1) } \\
\text { M. mycoides } \\
\text { subsp. mycoides LC }\end{array}$ & 1000 & 400 & $<10$ \\
\hline 3 & Y goat & 400 & 400 & $\gtrless 10$ \\
\hline 4 & F30 & 1000 & 400 & $<10$ \\
\hline 5 & VR13712.LB2 & $200-400$ & $200-400$ & 10 \\
\hline 7 & $74 / 2488$ & 400 & 200 & $<10$ \\
\hline 9 & $81.636 .1 \mathrm{C}$ & 40 & 20 & $10-40 \ddagger$ \\
\hline 11 & GE.6A.79E & $>1000$ & 400 & $80-100 \ddagger$ \\
\hline 13 & KH1 & 1000 & 400 & 80 \\
\hline 15 & Ojo 1 & 400 & 400 & $<10$ \\
\hline 16 & $78 / 441$ & 200 & $100-200$ & $<10$ \\
\hline 17 & $\operatorname{cov} 2$ & 1000 & 400 & $<10$ \\
\hline 18 & GM12 & 400 & 1000 & $<10$ \\
\hline \multirow[t]{2}{*}{21} & $1217 / 77$ & 400 & 200 & 10 \\
\hline & $\begin{array}{r}\text { Brazilian isolates } \\
\text { (? subsp. capri) }\end{array}$ & & & \\
\hline 22 & $\mathrm{G} 108 / \mathrm{A} 2$ clone $\mathrm{b}$ & 400 & 200 & $100-200$ \\
\hline 23 & G108/A2 clone $a$ & 400 & $400-1000$ & 400 \\
\hline 24 & G169/Leite & 400 & 200 & 10 \\
\hline 25 & G108/A3 & 1000 & 400 & 200 \\
\hline \multirow[t]{2}{*}{26} & G105/Al & 400 & 200 & 100 \\
\hline & $\begin{array}{l}\text { M. mycoides } \\
\text { subsp. capri }\end{array}$ & & & \\
\hline $2 ; 20$ & PG3 & $<10$ & 10 & 200 \\
\hline 1 & N108 & $<10$ & $200-400$ & 100 \\
\hline 6 & YC & $\gtrless 10$ & 200 & $40-100$ \\
\hline 8 & $\mathbf{Z Z}$ & $<10$ & $\gtrless 10$ & 100 \\
\hline 10 & $74.5907 \mathrm{~A}$ & $<10$ & $<10$ & 1000 \\
\hline 12 & $\mathbf{J M}$ & $<10$ & $<10$ & 400 \\
\hline 14 & Pendik & $<10$ & $<10$ & $400-1000$ \\
\hline 19 & BQT & $<10$ & $\gtrless 10$ & 200 \\
\hline 30 & $\begin{array}{l}\text { M. capricolum } \\
\text { (NCTC 10154) }\end{array}$ & $<10$ & $<10$ & $<10$ \\
\hline 28 & $\begin{array}{l}\text { Bovine serogroup } 7 \\
\text { (NCTC 10133) }\end{array}$ & $20-40$ & 50 & $<10$ \\
\hline
\end{tabular}

- Results with a PG1 reference antiserum (homologous titre 100) not included, as it failed to react with other SC strains, including Gladysdale; it also gave substantially negative results $(<20)$ with all other test strains shown in this table.

† Homologous titre for Gladysdale: 400.

$\ddagger$ These two strains gave negative results with an alternative PG3 antiserum prepared in this laboratory; for all the other test strains, this serum gave results similar to those shown above.

in other sub-phenons. Even at $90 \% S$, there were two mixed clusters. There was no evident correlation between protein-pattern classification and the presumed identities of strains - either subsp. mycoides LC or subsp. capri-as determined, in traditional manner, on mainly serological grounds. Comparison of all 25 test strains by the colony-IF method (Table 2) in general confirmed the presumed serological identities. Thus, strains labelled as subsp. capri reacted significantly with subsp. capri antisera, but not with subsp. mycoides antiserum, and most of the subsp. mycoides LC strains reacted strongly with the subsp. mycoides LC antiserum and were largely unreactive with the subsp. capri antisera. There were some anomalies however in both groups (LC and capri) of test strains. Strain no. 11 (GE.6A.79E), known to be cross-reactive with subsp. capri (G. S. Cottew, personal communication), did show such cross-reactivity by IF, 
as did strain no. $13(\mathrm{KH} 1)$ unexpectedly, while strain no. $9(81.636 .1 \mathrm{C})$, reportedly difficult to speciate (G. S. Cottew, personal communication), reacted only weakly with both subsp. mycoides and subsp. capri antisera. Among the nominal subsp. capri strains, there were two, nos 1 (N108) and 6 (YC), that were unexpectedly cross-reactive with subsp. mycoides LC antiserum while only moderately reactive with subsp. capri antisera. These various serological anomalies were not, however, reflected in any particular protein-pattern differences.

The Brazilian isolates (nos 22-26), provisionally classified as subsp. capri (Nascimento et al., 1986), were confirmed to be cross-reactive also with antisera to subsp. mycoides LC and to the 'Gladysdale' antiserum but not to the type-strain antiserum for subsp. mycoides (PG1). One of these strains, no. 22 (M108/A2 clone b), which had some cultural and serological differences from the others (Nascimento et al., 1986), was separated from them (but not from most subsp. mycoides LC and capri strains) in the protein pattern analysis at about $79 \% S$. However, the other four separated as a discrete group at $86 \% S$ and were still inseparable at $90 \% S$ despite one of them, no. 24 (G169/Leite), being unlike the others in showing no reaction with subsp. capri antisera in our IF tests (Table 2).

All the test strains were markedly glucose-fermenting and grew profusely in all culture media, producing large colonies on solid medium, as expected of subsp. capri and mycoides LC strains (Cottew, 1979). The Brazilian isolates conformed to these characteristics, except for strain no. 22 (G108/A2 clone b), which produced more moderate growth and smaller colonies, despite being indistinguishable serologically from G108/A2 clone a (strain no. 23) and two other Brazilian isolates.

\section{DISCUSSION}

These results confirm and extend the findings previously reported (Costas et al., 1987a) that most caprine mycoplasmas classified, on a serological basis, as either $\boldsymbol{M}$. mycoides subsp. mycoides LC or subsp. capri could not be separated from each other on the basis of their onedimensional SDS-PAGE protein patterns and mostly fell within one large phenon, embracing both subspecies. This phenon persisted at quite high levels of similarity and, not unexpectedly, also included strains that were serologically intermediate between the above two main groups. The phenon was also distinct from the representatives of the other four members of the ' $M$. mycoides cluster', including notably PG1, the type strain of subsp. mycoides (SC). It should be noted that PG1 had a protein pattern that was characteristic of the subspecies, when previously compared with three other SC strains (Costas et al., 1987a), despite its long passage history.

These findings provide further evidence in support of the concept that those $M$. mycoides strains that are more readily classifiable as either subsp. mycoides LC or subsp. capri fall at either end of a serological spectrum that also contains some serologically cross-reactive strains (Cottew, 1979), but whose members are all closely related in protein patterns. This concept supports the observations of Rodwell (1982; and as quoted by Cottew et al., 1987) stressing the close protein-pattern congruence he noted in the two-dimensional PAGE patterns of a collection of strains representative of subsp. mycoides LC (14 isolates) and capri (seven isolates). Rodwell also emphasized the closer similarity between the subsp. mycoides LC and capri strains than between either of them and subsp. mycoides SC (seven strains). These two-dimensional PAGE observations were further supported by those of Nascimento et al. (1986) and conflict with other reports of the DNA and protein relationships of the three groups (Askaa et al., 1978; Andersen et al., 1984), which suggested that SC and LC strains of subsp. mycoides were more clearly related to each other than to subsp. capri. Those studies were, however, limited by their use of only a single representative strain for each of the groups. Furthermore, despite their serological differences, the subsp. mycoides $L C$ and subsp. capri strains share several important biochemical and cultural characters that also distinguish them from the SC strains of subsp. mycoides (Cottew, 1979; Cottew et al., 1987). We would expect, on the basis of the above and our own observatons, that the reported DNA homology values between these three organisms would prove unrepresentative if a wider range of strains for each group were to be compared. Protein patterns obtained by one-dimensional SDS-PAGE provide an indirect measure of the coding 
capacity of the mycoplasmal genome, and comparison of such patterns ought therefore to provide an approximate reflection of probable genomic relationships, as has been shown for other bacteria (Owen \& Jackman, 1982; Costas et al., 1987b; Roop et al., 1985; Ursing \& Firehammer, 1985). Comparative DNA-homology studies have been proposed (Cottew et al., 1987) and are envisaged (Subcommittee, 1988) as part of an international programme intended to compare several representatives of each of the six members of the ' $M$. mycoides cluster' by DNA homology.

In the meantime, our studies strongly point to the future inclusion of subsp. capri, together with the LC strains currently classified under subsp. mycoides, within one taxon, which our previous studies suggest would be separate from subsp. mycoides SC (Costas et al., 1987a), and thus the classification of LC strains within subsp. mycoides would no longer be appropriate. Others have recognized the need for a revised classification of the three groups at present formally classified within the species $M$. mycoides, and various taxonomic schemes have been suggested, including the designation of LC and capri strains as serovars of subsp. capri (Salih $e t$ al., 1983; Cottew et al., 1987). This latter proposal would seem the most consistent with the results of our own one-dimensional SDS-PAGE protein pattern analyses.

This research was carried out in the framework of contract no. BAP. 0133 UK of the Biotechnology Action Programme of the Commission of the European Communities.

\section{REFERENCES}

Andersen, H., Christiansen, G. \& Christiansen, C. (1984). Electrophoretic analysis of proteins from Mycoplasma capricolum and related serotypes using extracts from intact cells and from minicells containing cloned Mycoplasma DNA. Journal of General Microbiology 130, 1409-1418.

AskaA, G., ErNø, H. \& OJo, M. O. (1978). Bovine mycoplasmas: classification of groups related to Mycoplasma mycoides. Acta veterinaria scandinavica 19, 166-178.

Costas, M., Leach, R. H. \& Mitchelmore, D. L. $(1987 a)$. Numerical analysis of PAGE protein patterns and the taxonomic relationships within the 'Mycoplasma mycoides cluster'. Journal of General Microbiology 133, 3319-3329.

Costas, M., OWEN, R. J. \& Jackman, P. J. H. (1987b). Classification of Campylobacter sputorum and allied campylobacters based on numerical analysis of electrophoretic protein patterns. Systematic and Applied Microbiology 9, 125-131.

Costas, M., Sloss, L. L., Owen, R. J. \& Gaston, M. A. (1989). Evaluation of numerical analysis of SDS-PAGE of protein patterns for typing Enterobacter cloacae. Epidemiology and Infection (in the Press).

CotTEW, G. S. (1979). Caprine-ovine mycoplasmas. In The Mycoplasmas, vol. II, pp. 103-132. Edited by J. G. Tully \& R. F. Whitcomb. London: Academic Press.

COTTEW, G. S. \& YeATS, F. R. (1978). Subdivision of Mycoplasma mycoides subsp. mycoides from cattle and goats into two types. Australian Veterinary Journal 54, 293-296.

Cottew, G. S., Breard, A., Da Massa, A. J., Ernø, H., Leach, R. H., LefeVre, P. C., RodWell, A. W. \& SMITH, G. R. (1987). Taxonomy of the Mycoplasma mycoides cluster. Israel Journal of Medical Sciences 23, 632-635.

Gardella, R. S., Delgiudice, R. A. \& Tully, J. G. (1983). Immunofluorescence. In Methods in Myco- plasmology, vol I, pp. 431-439. Edited by S. Razin \& J. G. Tully. London: Academic Press.

Nascimento, E. R., Nascimento, M. DA G. F., FreUNDT, E. A. \& ANDERSEN, H. (1986). Isolation of Mycoplasma mycoides from outbreaks of caprine mycoplasmosis in Brazil. British Veterinary Journal 142, 246-257.

OWEN, R. J. \& JACKMaN, P. J. H. (1982). The similarities between Pseudomonas paucimobilis and allied bacteria derived from analysis of deoxyribonucleic acids and electrophoretic protein patterns. Journal of General Microbiology 128, 2945-2954.

RoDWELl, A. W. (1982). The protein fingerprints of mycoplasmas. Reviews of Infectious Diseases 4, S8-S17.

ROOP, R. M., II, SMIBERT, R. M., JohnSON, J. L. \& KREIG, N. R. (1985). DNA homology studies of the catalase-negative campylobacters and 'Campylobacter fecalis', an emended description of Campylobacter sputorum, and proposal of the neotype strain of Campylobacter sputorum. Canadian Journal of Microbiology 31, 823-831.

Rosendal, S. \& Black, F. T. (1972). Direct and indirect immunofluorescence of unfixed and fixed mycoplasma colonies. Acta pathologica et microbiologica scandinavica B80, 615-622.

Salih, M. M., Simonsen, V. \& ERnø, H. (1983). Electrophoretic analysis of isoenzymes of $\mathrm{Myco}$ plasma species. Acta veterinaria scandinavica 24 , 14-33.

SubCommittee (1988). International Committee on Systematic Bacteriology Subcommittee on the Taxonomy of Mollicutes. Minutes of the interim meeting, 25 and 28 August 1986, Birmingham, Alabama. International Journal of Systematic Bacteriology 38, 226-230.

Ursing, J. \& FIrehammer, B. D. (1985). Genetic relationships between 'Campylobacter fecalis' and Campylobacter sputorum subsp. bubulus. Acta pathologica et microbiologica scandinavica B93, 377-378. 